Na zakończenie powtórzę cytat z Sørena Kierkegaarda, przytoczony w jednej z publikacji przez nauczyciela: „Uważa się powszechnie, że świat potrzebuje republiki, że trzeba ustanowić nowy porządek społeczny i nowa religię, a nikt nie myśli o tym, że światu zwichrzonemu zbyt wielką ilością wiedzy potrzeba nowego Sokratesa. Ale jest to zupełnie naturalne, bo gdyby ktoś jeden o tym pomyślał, albo wielu, zaraz by mniej jego było potrzeba" ${ }^{13}$.

\title{
Cele kształcenia w dydaktyce Drugiej Rzeczypospolitej i ich odbicie w niektórych programach nauczania dla szkoły ogólnokształcącej w latach 1920 - 1922
}

\section{Wprowadzenie}

Przedmiotem rozważań prezentowanych $w$ niniejszym artykule jest próba odpowiedzi na następujące pytanie: czy i jakie cele kształcenia funkcjonujące na gruncie międzywojennej dydaktyki jako dyscypliny znalazły swoje odzwierciedlenie w niektórych programach nauczania dla szkoły ogólnokształcącej w latach 1920-1922? Za podstawę dla prowadzonych analiz przyjęto program nauczania dla siedmioletniej szkoły powszechnej oraz program nauczania dla szkoły średniej ogólnokształcącej (wydział humanistyczny i matematyczno-przyrodniczy) ze szczególnym uwzględnieniem dwóch przedmiotów nauczania: języka polskiego i przyrody (przyrodoznawstwa). W odniesieniu do sformułowanego wcześniej pytania badawczego treść niniejszego artykułu ujęto $w$ trzy integralnie powiazane ze sobą części. W części pierwszej przedstawiono - z konieczności $w$ dużym skrócie - cele kształcenia funkcjonujące na gruncie polskiej dydaktyki jako dyscypliny w okresie Drugiej Rzeczypospolitej '. Część druga stanowi próbę ukazania problematyki odbicia celów kształcenia formułowanych $w$ obrębie międzywojennej dydaktyki jako dyscypliny w niektórych programach nauczania dla szkoły ogólnokształcącej w latach 1920-1922. W części trzeciej, zatytułowanej „Zakończenie" zawarto wnioski wynikające $\mathrm{z}$ badań.

\section{Cele kształcenia funkcjonujące na gruncie międzywojennej dydaktyki jako dyscypliny}

Zarówno w okresie Drugiej Rzeczypospolitej, jak i współcześnie pojawiały się i nadal pojawiają dość kontrowersyjne sady na temat celów kształcenia formułowanych w obrębie dydaktyki jako dyscypliny. W latach międzywojennych występowało wiele zróżnicowanych stanowisk w zakresie celów kształcenia, zdeterminowanych dynamicznym rozwojem w owym okresie różnych ideologii, nurtów filozoficznych, odmiennych systemów wartości. Spory w międzywojniu dotyczyły nie tylko treści celów kształcenia, ale także ich istoty, hierarchii oraz klasyfikacji. Kontrowersje wokól celów kształcenia rodzily się często przy okazji prób ustalenia miejsca teleologii w pedagogice $\mathrm{i}$ dydaktyce ${ }^{2}$.

${ }_{13}^{13}$ J. Trytek, Postmodernizm a nauczanie matematyki, „Matematyka” 2002, nr 337 (LV), s. 340.

' Szerzej problematykę celów ksztalcenia w dydaktyce Drugiej Rzeczypospolitej wraz z jej wielorakimi uwarunkowaniami przedstawiłam w swojej pracy, pt. „Cele kształcenia w dydaktyce Drugiej Rzeczypospolitej” (zob. V. Rodek, Cele ksztatcenia w dydaktyce Drugiej Rzeczypospolitej, Katowice 2003).

${ }^{2}$ D. Drynda, Pedagogika Drugiej Rzeczypospolitej. Warunki, orientacje, kontrowersje, Katowice 1987, s. 155; por. J. Kreutz-Mirski, Rozwazania nad pedagogika naukowa, „Ruch Pedagogiczny” 1918, nr 7-10. 
W związku z powyższym w początkowej fazie badań dużą trudnością było wyodrębnienie pewnych podstawowych tendencji występujacych w obrębie dydaktyki jako dyscypliny oraz formułowanych w jej obrębie celach kształcenia w okresie Drugiej Rzeczypospolitej. Po przeanalizowaniu $i$ ocenie wielu materiałów źródłowych uznano, że $w$ niniejszych badaniach można przyjąć trzy podstawowe ujęcia dydaktyki jako dyscypliny, wynikajace z głównych założeń pedagogiki herbartowskiej, pragmatycznej oraz pedagogiki kultury, a w związku z tym trzy różne koncepcje celów kształcenia. Spróbujmy teraz w sposób syntetyczny dokonać ich prezentacji.

W obrębie dydaktyki opartej na głównych przesłankach pedagogiki herbartowskiej, cele kształcenia utożsamiano z założonymi wcześniej, pożądanymi zmianami w charakterze uczniów wywołanymi przez działalność metodyczną nauczyciela. Ich źródeł upatrywano w filozofii, w racjonalistycznym i sensualistycznym nurcie poznania. Wyróżniano dwa rodzaje celów: cel końcowy i cele etapowe. Celem końcowym stawał się generalny cel wychowania, za który uznawano przeważnie wyrobienie szlachetnego charakteru moralnego, charakteru religijno-moralnego, etycznego. Celami etapowymi były natomiast integralnie połaczone ze sobą cele materialny i formalny. Realizacja tych celów stawała się niezbędnym warunkiem urzeczywistnienia celu końcowego. Takie ujęcie celów kształcenia może świadczyć o ich hierarchicznym układzie ${ }^{3}$.

Oparcie dydaktyki na głównych założeniach pedagogiki pragmatycznej spowodowało radykalne zmiany w problematyce dotyczącej celów kształcenia, charakterystycznej dla dydaktyki wywodzącej swoje tezy z głównych założeń pedagogiki herbartowskiej. Naturalistyczny a nawet pajdocentryczny punkt widzenia na proces uczenia się, a także pojmowanie człowieka jako istoty nieustannie rozwijajacej się w aktach własnego działania, determinowało poszukiwanie źródeł celów kształcenia $w$ indywidualnych skłonnościach jednostki do działania, jej potrzebach, wrodzonych instynktach, nabytych predyspozycjach, a także zainteresowaniach. Dynamiczny i zmienny charakter celów kształcenia spowodował trudności w wyodrębnieniu w niniejszych badaniach jakiś typowych rodzajów celów kształcenia funkcjonujących na gruncie dydaktyki opartej na zalożeniach pedagogiki pragmatycznej. Pozwolił też na sformułowanie wniosku, iż wzajemne relacje zachodzące pomiędzy tymi celami nie miały - w przeciwieństwie do koncepcji herbartowskiej - charakteru hierarchicznego.

Następna grupa celów kształcenia były cele funkcjonujące w dydaktyce opartej na ideach pedagogiki kultury, która zapoczątkowała zwrot w edukacji ku aksjologii i rozwijała się najbardziej intensywnie w naszym kraju w latach 30-tych XX wieku. Jej przedstawiciele w Polsce wyprowadzali cele kształcenia $\mathrm{z}$ filozofii kultury $\mathrm{i}$ teorii wartości. Utożsamiali je często $\mathrm{z}$ absolutnymi, ponadczasowymi wartościami stanowiącymi kulturę, co nadawało tym celom szczególną rangę w procesie ksztaltowania się osobowości człowieka. Rozwijanie osobowości w myśl wartości stało się mottem przewodnim rozważań teleologicznych m.in. S. Hessena i B. Nawroczyńskiego. W koncepcji „dydaktyki krytycznej” S. Hessena można wyróżnić trzy rodzaje celów kształcenia: cel końcowy, etapowy oraz cele pośrednie. Celem końcowym był wszechstronny rozwój osobowości ucznia, odbywający się w twórczym dochodzeniu do prawdy o sobie $\mathrm{i}$ świecie $\mathrm{w}$ procesie wychowania naukowego, nie różniącego się $w$ zasadzie od poznania naukowego. A jeśli tak, to głównym celem nauczania należało uczynić - według S. Hessena - opanowanie przez uczniów metody badań naukowych. Cel ten miał charakter etapowy w stosunku do celu końcowego. Realizacja głównego celu nauczania rozkładała się na trzy etapy, odpowiadające trzem poziomom nauczania realizującym cele pośrednie. Z powyższych rozważań

${ }^{3}$ Herbartowską teorię nauczania wychowującego oraz wynikająca z niej koncepcję celów kształcenia rozwijali w międzywojennej Polsce m.in. A. Danysz, M. Baranowski, ks. J.T. Peche, Sz. Matusiak, ks. W, Kosiński (zob. A. Danysz, O ksztalceniu, Lwów 1918; M. Baranowski, Pedagogika. Do uzytku seminariów nauczycielskich i nauczycieli szkót ludowych, Warszawa 1918; J.T. Peche, Pedagogika. Podrecznik szkolny w zakresie nauczania średniego. Opracowany wedlug najnowszych wskazań wychowawczych, Warszawa 1918; Sz. Matusiak, Wiadomości z pedagogiki i dydaktyki, Lwów 1921; W. Kosiński, Dydaktyka, Sandomierz 1924). 
wynika, że układ celów kształcenia zaproponowany przez S. Hessena miał charakter wyraźnie hierarchiczny ${ }^{4}$.

B. Nawroczyński wyróżnił z kolei dwa rodzaje celów kształcenia: cel końcowy, będący w jego koncepcji najwyższym idealem dydaktycznym oraz cele etapowe, związane z wyodrębnionymi przez niego typami nauczania, mającymi przybliżyć w konsekwencji wychowanka do owego wzoru, ideału. Najniższy stopień nauczania, czyli nauczanie informujące realizowało minimalny cel kształcenia, czyli nabywanie przez uczniów wiadomości i sprawności. Drugi stopień - nauczanie ćwiczące prowadziło do wyćwiczenia dyspozycji umysłowych. Wszystkie czynności, zwiazane z nabywaniem wiedzy, sprawności, ćwiczeniem dyspozycji umysłowych nabierały głębokiego sensu dopiero wtedy, gdy zmierzały do ukształtowania człowieka, odpowiadającego najgłębszym potrzebom danej epoki, danego społeczeństwa i wytworzonej przez niego kultury. Temu celowi służyło nauczanie kształcace. W hierarchicznym układzie celów kształcenia, zaproponowanym przez B. Nawroczyńskiego cele poznawcze zostały podporządkowane celom motywacyjnym, jednakże owo podporzadkowanie miało bardziej złożony charakter, niż w przypadku koncepcji herbartowskiej, czy poglądów S. Hessena, opierało się bowiem na zasadzie wzajemnego zawierania się celów niższego rzędu w celach wyższego rzędus.

\section{Odbicie celów kształcenia funkcjonujących na gruncie międzywojennej dydaktyki jako dyscypliny w niektórych programach nauczania dla szkoły średniej ogólnokształcącej w latach 1920 - 1922}

\section{Sytuacja szkolnictwa powszechnego oraz średniego ogólnokształcącego po} odzyskaniu niepodległości. Pierwsze prace programowe

Wybuch pierwszej wojny światowej w 1914 roku rozbudził nadzieję narodu polskiego na odzyskanie niepodległości. W wielu ośrodkach na ziemiach polskich, a częściowo także na emigracji, na przykład w Austrii i Rosji, podjęto przygotowania do zaprojektowania organizacji przyszłego państwa, w tym również ustroju polskiego szkolnictwa i dostosowanych do niego nowych programów nauczania ${ }^{6}$. Istotną rolę $w$ pracach koncepcyjnych dotyczących wskazanych powyżej zagadnień odgrywały dwa ośrodki w kraju: krakowski i warszawski. Pierwszy z nich opracował projekt szkoły średniej, drugi natomiast zajął się szkoła powszechną. Dużym krokiem naprzód w rozstrzygnięciu sporów toczących się wokół ustroju przyszłego szkolnictwa był Pierwszy Ogólnopolski Wielki Zjazd Nauczycielski, zwany często Sejmem Nauczycielskim. Zwołany z inicjatywy K. Praussa w Warszawie w dniach 14-17 kwietnia 1919 roku Zjazd miał na celu przeanalizowanie ważniejszych zagadnień szkolnych oraz rozpatrzenie projektów ustaw zaproponowanych przez Ministerstwo Wyznań Religijnych i Oświecenia Publicznego?. W czasie jego obrad przedyskutowano wiele, często kontrowersyjnych

${ }^{4}$ Zob. V. Rodek, op. cit., s. $117-132$; por. poglądy pedagogiczne S. Hessena zawarte w jego dzielach zatytułowanych: Podstawy pedagogiki, Warszawa 1931; O sprzeczności i jedności wychowania, Warszawa 1939.

${ }^{5}$ Najszerzej swoje poglądy na temat dydaktyki oraz celów kształcenia B. Nawroczyński przedstawił w dziele pt. „Zasady nauczania" (zob. B. Nawroczyński, Zasady nauczania, Lwów-Warszawa 1930; por. V. Rodek, op. cil., s. $132-145)$.

${ }^{6}$ W okresie Drugiej Rzeczypospolitej dwukrotnie podjęto prace nad programami nauczania. Pierwszy raz w początkach niepodległości, drugi natomiast w związku z reformą przeprowadzoną przez J. Jędrzejewicza. Pierwsze programy nauczania weszly w życie w latach $1920-1922$ (zob. J. Sobczak, "Nowe wychowanie” w polskiej pedagogice okresu Drugiej Rzeczypospolitej [1918-1922], Bydgoszcz 1998, s. 257).

Zob. np. M. Falski, Koncepcja szkoly powszechnej $i$ jej roli w ustroju szkolnym w okresie międzywojennym w Polsce [w:] Rozprawy z Dziejów Oświaty, t. I, Wroclaw 1958, s. 184 oraz M. Lipowska, Główne idee przewodnie w programach nauczania szkoły ogólnoksztatcacej w latach 1918 - 1975 [w:] Idee przewodnie w programach szkoty ogólnoksztalcacej w latach 1918-1978, red. T. Wróbel, Warszawa 1985, s. 40-41. 
projektów, a podejmowane polemiki odzwierciedlały złożony klimat polityczny, charakterystyczny dla pierwszych lat powojennych, w którym splatały się interesy różnych ugrupowań walczących o władzę

Postulaty wypracowane przez Sejm Nauczycielski zostały formalnie przedłożone Ministerstwu WRiOP w nadziei na dalsza owocna wspólpracę. Tymczasem pierwsze akty prawne, regulujące najbardziej naglące sprawy związane $\mathrm{z}$ polityka oświatową pominęly wiele wartościowych tez, przyjętych przez Sejm Nauczycielski.

Podstawy organizacyjno-programowe szkoły powszechnej określała ustawa sejmowa z dnia 17 lutego 1922 roku o zakładaniu i utrzymywaniu publicznych szkół powszechnych. Na mocy tej ustawy szkolnictwo elementarne przemianowano na powszechne oraz zapowiedziano objęcie wszystkich dzieci od 7 do 14 roku życia siedmioletnim obowiązkiem nauczania. Sposób realizacji tej ustawy okazał się jednak daleki od doskonałości. Dozwolona wielotorowość wypełniania obowiązku nauczania determinowała sieć szkolna, a także stopień organizacji publicznych szkół powszechnych, który był uzależniony od liczby dzieci w wieku szkolnym w danym obwodzie szkolnym na przestrzeni trzech lat po sobie następujacych. Szkoła siedmioletnia z siedmioma i więcej nauczycielami mogła zostać utworzona dopiero wtedy, gdy w obwodzie szkolnym było ponad trzysta dzieci w wieku obowiazku szkolnego?.

Trudną sytuację publicznego szkolnictwa powszechnego pogłębialy dodatkowo obowiąujace programy nauczania, oddzielne dla poszczególnych jego stopni organizacyjnych. Owo zróżnicowanie programowe wpływało na brak drożności pomiędzy szkolnictwem powszechnym a średnim. Warto jednak zauważyć, że siedmioklasowa szkoła powszechna, masowa i obowiązkowa, otwarta (przynajmniej teoretycznie) dla dzieci z wszystkich grup społecznych, realizowała podstawowy etap jednoczenia narodu i budowania świadomości społecznej. Proces ten odbywał się głównie dzięki treściom nauczania, tzw. osi programowej: „Polska i jej kultura”, a także poprzez wychowanie narodowe, stanowiące syntezę celów i zadań stawianych szkole powszechnej. Idea zjednoczenia narodu polskiego była obecna zarówno $w$ celach wychowawczych, jak i poznawczych wszystkich przedmiotów nauczania, zawartych w programic dla siedmioletniej szkoły powszechnej, stwarzajac tym samym podstawowe warunki demokratyzacji społeczeństwa polskiego ${ }^{10}$.

Z kolei organizacja i zadania szkolnictwa średniego ogólnokształcacego wynikały - do chwili wejścia w życie ustaw jędrzejewiczowskich - z opracowanego przez Ministerstwo WRiOP i wydanego w 1919 roku projektu „Program naukowy szkoły średniej ogólnokształcącej”. Program ten nieznacznie tylko zmodyfikowano w latach późniejszych przez ministerialne rozporządzenia i okólniki. Do końca roku szkolnego 1928/29 przyjęcia do szkoły średniej odbywały się na podstawie egzaminów wstępnych, a nie świadectwa ukończenia odpowiedniej szkoły powszechnej. Szkolnictwo średnie charakteryzowało się poza tym znaczną dyferencją programowa, uniemożliwiająca uczniom ewentualne przejście w trakcie nauki do innego typu szkoły średniej. Głównym zadaniem szkoły średniej ogólnokształcącej było przygotowanie kandydatów do studiów w uczelniach wyższych, zgodnie z przyjętą na Sejmie Nauczycielskim koncepcja utworzenia nowej inteligencji polskiej, potrzebnej do odbudowy i budowy ekonomiczno-gospodarczej bazy kraju.

Przyjrzyjmy się teraz bliżej niektórym programom nauczania dla szkoły ogólnokształcącej pod kątem zawartych w nich celów kształcenia w latach 1920-1922.

\footnotetext{
${ }^{8}$ Znaczne kontrowersje wzbudził na przykład projekt Ministerstwa dotyczący zakładania czteroletnich szkół wydziałowych, opartych na trzech klasach szkoły powszechnej. Polscy nauczyciele byli przeciwni kierowaniu uczniów do szkół wydziałowych. Opowiedzieli się za szkolnictwem średnim pięcioletnim, zbudowanym na podstawie pełnego programu szkoły powszechnej siedmioklasowej. Sprzeciwiali się tym samym nadawaniu klasie VII tej szkoły charakteru programowej „czapki” (F.W. Araszkjewicz, Geneza ustaw z roku 1932 o szkolnictwie państwowym i prywatnym, „Przegląd Historyczno-Oświatowy” 1971, nr 4, s. 549-550).

"Dla 60 dzieci organizowano szkoly jednoklasowe z jednym nauczycielem, dla 100 wychowanków - szkoły dwuklasowe z dwoma nauczycielami, dla 101 - 150 uczniów - szkoły trzyklasowe z trzema nauczycielami (ibidem, s. 550).
}

${ }^{10}$ M. Lipowska, Glówne idee przewodnie w programach nauczania..., s. 42-43. 


\section{Programy nauczania dla siedmioletniej szkoły powszechnej oraz szkoły}

średniej ogólnokształcacej (wydział humanistyczny i matematyczno-przyrodniczy) z lat 1920-1922 w kontekście celów kształcenia formułowanych na gruncie międzywojennej dydaktyki jako dyscypliny

W pierwszych latach po odzyskaniu niepodległości wciąż żywa była w Polsce koncepcja dydaktyki oparta na podstawowych założeniach pedagogiki herbartowskiej. Przypomnijmy, iż cele kształcenia funkcjonujace $w$ jej obrębie miały charakter materialny $\mathrm{i}$ formalny. Przedstawiciele i zwolennicy tej dydaktyki postulowali integralne połączenie ze sobą wyżej wymienionych celów uważając, że dominacja któregoś z nich może przynieść negatywne konsekwencje dla całego procesu kształcenia.

$\mathrm{W}$ analizowanych programach nauczania dla siedmioletniej szkoły powszechnej znalazły swoje odbicie zarówno materialne, jak i formalne cele kształcenia, przy czym zaznaczyła się jednak wyraźnie dominacja celów formalnych. Już w czasie obrad Sejmu Nauczycielskiego M. Reiter zauważył: „Program naukowy daży do wyrobienia u mtodzieży pewnej sprawności umystowej, stosownie do wieku", a T. Łopuszański stwierdzit: ,Nie ma co troszczyć się o to, czy uczeń jakiś przedmiot umie lub nie, chodzi o to, by ze szkoty wyszedt silny umystowo" ". Tendencja do uprzywilejowania celów formalnych była najlepiej widoczna w programie nauczania dla szkoły powszechnej w przedmiocie - język polski, czego dowodem może być następujący sposób formułowania prawie wszystkich wymienionych w nim celów:

,1. Rozumienie mowy, która w obcowaniu codziennym postuguje się oświecony ogót narodu polskiego; 2. Rozumienie jezyka ksiazkkowego: a) prozy (...); b) języka poetyckiego (...); 3. Wzbudzenie zamilowania $i$ wyrobienie uzdolnienia do czytania jako środka ksztatcacego umysl i serce (...)" ${ }^{\prime 2}$. I chociaż w drugim cyklu nauki (w klasach V-VII) wprowadzono podstawowe pojęcia ze składni zdania pojedynczego i złożonego, z fleksji (deklinacja i koniugacja) oraz fonetyki i ze slowotwórstwa, to jednak wyraźnie zaznaczono, iż nie stanowią one odrębnego działu nauczania, lecz łączą się ściśle z ćwiczeniami w mówieniu i pisaniu. Kurs gramatyki na tym stopniu - jak czytamy w programie - „opierajac sie na poprzednich wiadomościach, pogłębia je o tyle, aby uczeń kończacy szkote podstawowa zdawat sobie sprawe $z$ najwazniejszych zjawisk jezzkowych, a zarazem, aby poza ich analiza uczyt się myśleć i rozumować logicznie" ${ }^{13}$.

W nauczaniu przyrody natomiast, jako pierwszy wymieniono wprawdzie cel materialny: ,Zaznajomienie $z$ najważniejszymi zjawiskami $i$ prawami przyrody zywej $i$ martwej oraz ich zastosowaniami praktycznymi”, ale już następne cele: „Zaprawienie do bystrej i ścistej obserwacji i wyrobienie zdolności logicznego myślenia", a także: ,Wyrobienie inicjatywy i samodzielności w pracy, zręczności i praktyczności" ${ }^{14}$, miały charakter formalny. Poza tym wskazówki metodyczne osłabiały w pewien sposób wymowę wskazanego wcześniej celu materialnego poprzez stwierdzenie, iż ,Nauki przyrodnicze maja na celu nie tylko zdobycie pewnej sumy wiadomości, lecz w pierwszej mierze (podkr. - V.R.) ksztatcenie pewnych władz umysłowych, które przy pomocy tych przedmiotów naukowych przede wszystkim kształcić się dadza" ${ }^{15}$. Tak więc tendencja do utrzymywania równowagi pomiędzy celami materialnymi i formalnymi została w programie nauczania dla siedmioletniej szkoły powszechnej zachwiana. Poza tym cele kształcenia w dydaktyce opartej na podstawowych ideach pedagogiki herbartowskiej tworzyły układ hierarchiczny, gdyż dwa integralnie połączone ze sobą cele - materialny i formalny miały zmierzać w konsekwencji do urzeczywistnienia generalnego celu wychowania, jakim było wyrobienie silnego moralnie charakteru lub charakteru religijno-moralnego ${ }^{16}$. Tymczasem cele

${ }^{11}$ O szkotę polska, cz. 3, s. 93 i 95.

12 Por. Aneks nr 1.

${ }^{13}$ Wskazówki metodyczne do programu nauki w szkole powszechnej siedmioklasowej. Język polski, Warszawa 1920 , s. 60.

14 Por. Aneks nr 1.

${ }_{15}$ Program gimnazjum państwowego, wydziat malematyczno-przyrodniczy, Warszawa 1922, s. 18.

16 V. Rodek, op. cit., s. $66-67$. 
zawarte w programie nauczania dla siedmioletniej szkoły powszechnej nie były powiązane ze sobą w jedna całość określoną myśla przewodnią. W sposobie ich prezentacji dawał się odczuć brak jakiegokolwiek kryterium, wskazującego na stopień ważności celów. Niektóre z nich wymieniano jako ostatnie w dziale „Cel nauki”, natomiast we wskazówkach metodycznych znajdowały się one na miejscu pierwszym i podkreślano ich decydujące znaczenie dla procesu nauczania danego przedmiotu ${ }^{17}$. Co więcej, można odnieść wrażenie, jakby cele nauczania były formułowane osobno w każdym przedmiocie, w izolacji od siebje, wynikajacej z przekonania o konieczności ich dostosowania do specyficznej treści poszczególnych przedmiotów, jednym słowem zostaly one przedstawione w sposób dość chaotyczny i bezładny. Wymieniane w programie cele nie stanowiły jakiegoś zwartego systemu wychowawczego. Podkreślano w nich, natomiast, pewne akcenty narodowe, łączace się głównie z celami nauki o Polsce, na przykład wyróżniony w języku polskim cel: „świadome umitowanie języka polskiego" ${ }^{18}$. Jedynje w programie religii podano ogólny cel, pretendujacy do roli syntezy wychowawczej, a mianowicie: "nadanie całemu wychowaniu charakteru religijno-moralnego ${ }^{\prime \prime}{ }^{19}$. Cel ten nie występowal jednak $w$ innych przedmiotach nauczania, gdyż brakowało $w$ nich sformułowań w sensie uniwersalizmu moralnego.

W ten sposób strona wychowawcza wykształcenia posiadała rys narodowy, skupiony $w$ treściach nauki o Polsce współczesnej, która ,pokazuje zwiazek życia narodu z ziemia zyycia jednostki z życiem społeczeństwa, przygotowuje do zrozumienia zadań obywatela Rzeczypospolitej" ${ }^{20}$, a także nabierała akcentu religijno-moralnego, ale tylko w nauczaniu religii.

W większym stopniu cele kształcenia funkcjonujące na gruncie dydaktyki, wywodzacej swoje tezy z podstawowych założeń pedagogiki herbartowskiej, znalazły swoje odbicie $w$ programie nauczania dla szkoły średniej ogólnokształcacej (wydział humanistyczny i matematyczno-przyrodniczy) ${ }^{21}$. Wprawdzie w programie tym dalej zaznaczała się przewaga celów formalnych, to jednak przyjęta przez szkołę zasada podstawy dydaktycznej ${ }^{22}$ stanowila w praktyce kompromis pomiędzy formalizmem a materializmem dydaktycznym. Podstawa dydaktyczna akcentowała bowiem konieczność uzyskania wykształcenia ogólnego na różnorodnych, ale jednostronnie dobranych treściach, a jednocześnie możliwie wysokiego, wszechstronnego rozwoju inteligencji człowieka, jego myślenia, zdolności obserwacji, kombinowania, wnikliwości, itp. ${ }^{23}$ Ogólny cel szkoły średniej ogólnokształcącej uszczegółowiony w różny sposób

17 Por. np. Program nauki w szkolach powszechnych siedmioklasowych. Jezyk polski, Warszawa 1920, s. 3, 15.

18 Ibidem, s. 3.

19 Program nauki $w$ szkotach powszechnych siedmioklasowych. Religia rzymsko-katolicka..., s. 3.

${ }_{20}$ Pod. za M. Lipowska, Koncepcja wyksztalcenia ogólnego w programach szkoly polskiej w latach 1919-1922, Toruń 1961 , s. 85.

${ }_{21}$ Szkoła średnia, czyli gimnazjum realizowała pełny proces wykształcenia ogólnego, tzn. poziom podstawowy i średni. Jej wyższe klasy - od IV do VIII - zróżnicowano na zasadzie podstawy dydaktycznej, zwanej wcześniej wychowawcza, na trzy wydziały: matematyczno-przyrodniczy, humanistyczny z lacina i klasyczny. Dla tych trzech typów szkó opracowano w latach 1919-1922 programy. W klasach I-III obowiazywał jednakowy program dla wszystkich szkół średnich. Realizację wykształcenia ogólnego zaprojektowano zatem w ramach dawnej organizacji ośmioklasowego gimnazjum, jednakże wyodrębniono dwa poziomy: niższy - trzyletni, który w przyszłości mial polączyć się ze szkołą powszechną oraz wyższy - pięcioletni, składajacy się z trzech typów. W ten sposób uczeń miał mieć zapewnioną indywidualna drogę rozwoju, indywidualny poziom i rodzaj wykształcenia jako jej rezultat. Wykształcenje ogólne w szkole średniej miało taki sam charakter ideologiczny jak w szkole powszechnej. W obu przypadkach chodziło bowiem o ksztalcenie narodu polskiego, oparte na treściach kultury polskiej i podporzadkowane idei wychowania narodowego. Szkola średnia nie była jednak szkoła masową, realizowała program na wyższym poziomie, a także dażyła do urzeczywisınienia sobie tylko właściwego zadania, a mianowicie kształtowania inteligencji polskiej. Te dwa założenia stanowily treść wyksztalcenia ogólnego, uwzględniana w odpowiednich proporcjach w przedmiotach nauczania we wszystkich typach szkół (M. Lipowska, Koncepcja wykształcenia ogólnego..., s. 100 - 101).

${ }_{22}$ Przy podstawie tej chodzilo o ograniczenie ilości równocześnie nauczanych przedmiotów i zakresu ich treści, po to aby można było zachować wolniejsze tempo pracy, osiagnąć lepszą koncentrację uczniów w nauce oraz wprowadzić metode pracy samodzielnej według zasady - „uczymy się przez działanie”. Przedmioty nauczania podzielono na dwie grupy. Jedne $z$ nich stanowiły podstawę dydaktyczna i miały odgrywać glówną roię w rozwoju myślenia uczniów, drugie natomiast pełnily funkcje informacyjne, konieczne ze względu na rozwój i zachowanie jedności ku]tury narodu, techniki, życia społecznego, itp. (ibidem, s. 100-101).

${ }^{23}$ M. Lipowska, Glówne idee przewodnie w programach nauczania szkoly ogólnoksztatcacej $w$ latach $1918-1975 \ldots$, s. 44 ; zob. także M. Lipowska, Koncepcja wyksztatcenia ogólnego w programach szkoty polskiej w latach $1919-1922 \ldots$, s. 111 . 
w celach i treściach nauczania każdego przedmiotu sformułowano w myśl formalizmu dydaktycznego ${ }^{24}$, ale w programie nauczania języka polskiego można zauważyć pewną dążność do zachowania równowagi pomiędzy celami materialnymi i formalnymi. Cele materialne sformułowano następujaco: „,doprowadzić do zrozumienia podstawowych właściwości wspótczesnego języka polskiego z uwzględnieniem jego rozwoju w ciagu ubieglych wieków", ,doprowadzić do gruntownego przyswojenia sobie wybranych arcydziel literatury polskiej i powszechnej". Wśród celów formalnych znalazły się, natomiast, takie określenia jak: „nauczyć się biegle mówić i pisać, zaprawić do jasnego, rzeczowego i możliwie samodzielnego myślenia, ksztatcić wyobraźnię i smak estetyczny" ${ }^{25}$.

Pewna tendencja do zachowania równowagi pomiędzy tymi dwoma grupami celów uwidoczniła się również w programie nauczania przyrodoznawstwa, chociaż większy nacisk niż w programie języka polskiego położono tutaj na cele formalne.

Poza tym, w analizowanych programach nauczania dla szkoły średniej ogólnokształcacej z lat 1920 - 1922 wystąiła - w odróżnieniu od programu nauczania dla siedmioletniej szkoły powszechnej - próba uhierarchizowania celów kształcenia, wykazująca pod względem formalnym pewne podobieństwo do propozycji herbartowskiej. We wskazówkach metodycznych do programu języka polskiego przyjęto bowiem za najważniejszy, generalny cel kształcenia - „wychowanie czlowieka $i$ obywatela przez wpajanie świadomej mitości języka ojczystego i kultury narodowej (...)"26. Zaproponowane przez program cele materialne i formalne miały zmierzać w konsekwencji do jego urzeczywistnienia. Wiedza stawała się w tym przypadku nie celem ostatecznym, lecz etapem wejścia na wyższy poziom życia umysłowego i moralnego. Ogólne wykształcenie intelektualne wchodziło zatem w zakres wychowania i stanowiło równocześnie jeden ze środków dla osiągnięcia nakreślonych celów wychowania dzięki treściom o zabarwieniu moralnym i narodowym. Trzeba jednak wspomnieć, że hierarchiczny układ celów, widoczny we wskazówkach metodycznych do nauczania języka polskiego nie był konsekwentnie przestrzegany. Nie znalazł odbicia w prezentowanych przez program celach nauczania tego przedmiotu. Generalny cel kształcenia został tutaj zamieszczony wśród celów formalnych na ostatniej pozycji i gdyby nie wskazówki metodyczne nic nie wskazywałoby na jego szczególne znaczenie w procesie dydaktycznym.

Przewaga celów formalnych $w$ analizowanych programach nauczania zarówno dla siedmioletniej szkoły powszechnej, jak i szkoły średniej ogólnokształcącej w latach 1920-1922 wskazuje na wpływy idei „nowego wychowania". Już w trakcie prac nad projektami pierwszych programów dla szkół ogólnokształcących w Polsce, prowadzonych przez ośrodek krakowski i warszawski w czasie pierwszej wojny światowej i tuż po niej, obecność tych idei była wprost namacalna. I nie chodziło tu tylko o uwzględnienie w projektach programów nowych przedmiotów o charakterze artystyczno-technicznym, ale także o przyjęcie za cel nauczania przygotowania ucznia do dalszej pracy samoksztatceniowej i samowychowawczej po ukończeniu szkoły. Dlatego też na pierwszy plan wysuwano formalne cele kształcenia. M. Lipowska pisze, iż pierwsze lata formułowania propozycji programowych dla szkoły w wolnej Polsce były okresem ulegania ofensywnym ideom "nowego wychowania”. W efekcie działania uroku nowości i postępowości programu „nowego wychowania" nowatorskie hasła psychologizmu stały się naczelną ideą szkoły polskiej ${ }^{27}$. Zdaniem B. Nawroczyńskiego praca nad programami szkół publicznych i państwowych tworzyła atmosferę zaangażowania poszczególnych jednostek

${ }^{24}$ Ogólny cel szkoły ŝredniej ogólnokształcącej brzmiał następująco: „Zadaniem szkoły średniej jest rozwijanie fizycznych, intelektualnych i moralnych sit mtodziezy. Wszelkie inne cele jak przygotowanie do studiow wyzszych, nie moga być miarodajne dla ustroju, programu i melod szkoty średniej, moga tylko o tyle być podejmowane przez nia o ile nie utrudniaja osiagnięcia glównego celu, którym jest rozbudzenie intelektualnych zamitowan, uzdolnień do samodzielnej pracy $i$ wszechstronnego rozwoju duchowego. Szkoła średnia przygotowuje do szkoły wyższej, ale nie w ten sposób, izby ladowala $w$ ucznia pewien zasób wiadomości uznanych za potrzebne. Wlaśnie rozwój władz umysłowych, wyrobienie samodzielności, umiejętności stawiania sobie $i$ rozwiazywania zagadnień stanowi istotne przygotowanie zarówno do szkoty wyższej, jak $i$ do zycia" (O szkote polska, cz. 3, s. 90).

25 Por. Aneks nr 2.

${ }^{26}$ Wskazówki metodyczne do programu gimnazjum państwowego. Wydzial humanistyczny (jęzk polski), Warszawa 1922 , s. 48.

${ }_{27}$ M. Lipowska, Koncepcja wyksztatcenia ogólnego w programach szkoty polskiej..., s. 41. 
w sprawy nowoczesnego - z punktu widzenia pedagogiki i dydaktyki - ujęcia organizacji oraz programów nauczania. I właśnie w tej atmosferze - pisze B. Nawroczyński - zrodziły się ksiażki H. Rowida i J. Ostrowskiego, dajace, obok teorii nowej szkoły, szczególowo opracowane projekty wcielania tej teorii $w$ życie ${ }^{28}$.

Nowe trendy obecne $w$ analizowanych $w$ niniejszym artykule programach nauczania determinowały - obok przewagi formalizmu dydaktycznego - także praktyczny charakter zawartych w nich celów. Wszechobecność utylitaryzmu wyrażała się z jednej strony w trosce o przydatność treści i funkcji myślenia w życiu codziennym, z drugiej zaś w akcentowaniu praktycznych metod zdobywania tej wiedzy. W pierwszym przypadku chodziło o taki dobór materiału nauczania, aby uzyskać na nim wyćwiczenie zręczności i zdobyć funkcje myślenia niezbędne dla właściwego funkcjonowania w otaczającym dziecko świecie. Utylitaryzm uwidocznił się szczególnie w programie nauczania na szczeblu elementamym. W celach nauczania języka polskiego podkreślano, na przykład, rozumienie mowy, jaką posługuje się naród polski w życiu codziennym, a także nabycie praktycznej umiejętności wyrażania się w mowie oraz piśmie. Podobnie w celach nauczania przyrody akcentowano - obok zapoznawania uczniów z wiedzą dotyczącą najważniejszych zjawisk i praw przyrody - także jej praktyczne zastosowanie. W treściach programowych, odpowiadających tematycznie porom roku dbano o takie ich ułożenie, aby nauczyciel mógł omawiać rośliny i zwierzęta, a także zjawiska dostępne i występujące aktualnie w przyrodzie. Ciągle odwoływano się do upraktycznienia zdobywanej wiedzy, wykorzystywania pomocy dydaktycznych, wykonywania doświadczeń, co wiązało się z drugim rozpatrywanym tutaj zagadnieniem, dotyczącym praktyczności w metodzie nauczania. Owa praktyczność polegała nie na tym, aby wychowanek rozumiał naukowe uzasadnienie tego, czego się uczy, ale na tym, aby potrafił umiejętnie posługiwać się nabyta wiedza. W programie nauczania języka polskiego dla siedmioletniej szkoły powszechnej czytamy na przykład - ,Nauka ma na kazdym stopniu charakter wybitnie praktyczny; wszelkich teoretycznych wywodów należy zaniechać, gdyz nalezyta wprawe u dzieci w poprawnem wyrazaniu swych myśli w mowie $i$ w piśmie osiaga się przede wszystkim przez systematyczne i celowe ćwiczenia jezzykowe" ${ }^{29}$. Nauka miała polegać zatem na ćwiczeniach w mówieniu, pisaniu, objaśnianiu oraz opracowywaniu odpowiednio dobranych fragmentów tekstu, na praktycznych ćwiczeniach gramatycznych i stylistycznych. Chodziło więc bardziej o powstanie pewnych nawyków, czyli mechanicznych sposobów zachowania się, niż o świadome i uzasadnione rozumowo wiadomości oraz umiejętności.

W programie nauczania przyrody na poziomie elementarnym realizację wszystkich celów uzależniano od metody nauczania opartej na samodzielnej pracy uczniów. ,,Podawanie dziecku gotowej wiedzy przez nauczyciela daje mu w najlepszym razie pewien zasób materialnej wiedzy - zreszla nie przyswojonej na trwale - ale zupetnie nie wplywa na rozwój wladz umystowych" ${ }^{30}$. W zwiazku z tym za podstawę nauczania tego przedmiotu przyjęto czynny, bezpośredni stosunek wychowanka do nauki, oparty na obserwacji prowadzonej poza szkolą i jedynie kierowanej przez nauczyciela lub celowo zorganizowanej w szkole w postaci samodzielnych ćwiczeń wychowanka. Rola nauczyciela sprowadzała się do stopniowego poszerzania zakresu ,rzeczy" i zjawisk podlegajacych uwadze i spostrzeganiu dziecka oraz do pomocy w wysnuwaniu przez nie odpowiednich wniosków. Bezpośrednia praca ucznia na materiale przyrodniczym ,nie tylko pobudza umyst (...) do myślenia, nie tylko utrwala w umyśle zdobyte wiadomości, ale takze $w$ wysokim stopniu rozwija zainteresowanie uczniów, co jest wielka zdobycza metodyczna" ${ }^{31}$.

Ten utylitaryzm w pojmowaniu celów kształcenia wynikał prawdopodobnie z wpływów koncepcji nauki całościowej, związanej ideowo z dydaktyką opartą na podstawowych założeniach pedagogiki pragmatycznej. Koncepcja nauki całościowej, przyjmując tezę, że świat jest całością wysuwała postulat całościowego poznawania przez dziecko rzeczywistości. Stąd naukę organizowano wokół pewnych

\footnotetext{
28 B. Nawroczyński, Polska myśl pedagogiczna, Lwów-Warszawa 1938, s. 212-213.

29 Program nauki $w$ szkotach powszechnych siedmioklasowych. Jezyk polski.., s. 13-14.

${ }^{30}$ Program nauki $w$ szkotach powszechnych siedmioklasowych. Przyroda..., s. 18.

3 Ibidem, s. 19.
} 
zagadnień, wynikających z potrzeb umysłowych wychowanka, jego zainteresowań, przeżyć, działalności praktycznej, prowadzącej do działalności poznawczej, a nie wokół przedmiotów szkolnych. Naukę koncentrowano zatem na najbliższym środowisku dziecka, starając się, aby poznało je ono możliwie wszechstronnie. Podział na poszczególne przedmioty, zwłaszcza na poziomie klas I-II nabierał więc charakteru jedynie orientacyjnego. Koncepcja nauki całościowej byla wspierana przez ówczesne teorie psychologiczne, które uzasadniały synkretyczne spostrzeganie przez dziecko świata i uznawały, że dopiero na poziomie klasy III-IV uczeń potrafi wyodrębniać szczegóły w danej całości. Nauka całościowa zreformowała organizację nauczania przede wszystkim na szczeblu elementarnym oraz przyczynila się do uwzględnienia w programie nauczania na tym poziomie dwóch zasad: organizowania spontanicznej aktywności dziecka i praktycznego przygotowania uczniów do życia ${ }^{32}$.

W części pierwszej niniejszego artykułu zostały także zaprezentowane - obok propozycji herbartowskiej i pragmatycznej - cele kształcenia funkcjonujące na gruncie dydaktyki opartej na głównych ideach pedagogiki kultury. W związku z tym, że pedagogika kultury, stanowiąc próbę przezwyciężenia biopsychologicznej $\mathrm{i}$ socjologicznej teorii wychowania rozwijała się najbardziej intensywnie $w$ Polsce międzywojennej $w$ latach 30-tych, nie zaobserwowano w analizowanych programach nauczania odbicia koncepcji celów kształcenia proponowanych przez przedstawicieli tego nurtu. Dopiero w programach zreformowanej szkoły ogólnokształcącej (lata 1933-1939) można odnaleźć wyraźne wpływy pedagogiki kultury. Zagadnienie to stanie się przedmiotem szczegółowej analizy $\mathrm{i}$ oceny $\mathrm{w}$ kolejnym artykule.

\section{Zakończenie}

Analiza i ocena celów kszałcenia zawartych w programach nauczania dla siedmioletniej szkoły powszechnej oraz dla szkoły średniej ogólnokształcącej (wydział humanistyczny i matematyczno-przyrodniczy) wydanych w latach 1920-1922 uprawnia - jak się wydaje - do następujących wniosków:

1. W programach tych znalazły swoje odbicie cele materialne $\mathrm{i}$ formalne formulowane na gruncie dydaktyki opartej na podstawowych założeniach pedagogiki herbartowskiej. Nie można jednak mówić tutaj o pełnym odbiciu celów propagowanych przez przedstawicieli i zwolenników tej dydaktyki $w$ międzywojennej Polsce. $W$ analizowanych programach nauczania nie wystapiła bowiem - charakterystyczna dla dydaktyki czerpiącej swoje tezy z przesłanek pedagogiki herbartowskiej - tendencja do zachowania równowagi pomiędzy tymi dwiema grupami celów. Zarówno w programie nauczania dla siedmioletniej szkoły powszechnej jak i dla szkoły średniej ogólnokształcacej zaznaczyła się przewaga celów formalnych. Jedynie w programie nauczania języka polskiego na poziomie średnim gimnazjalnym można zauważyć większą dbałość o materialne cele nauczania. Tutaj również pojawiła się próba uhierarchizowania celów podobna - ale tylko pod względem formalnym - do propozycji herbartowskiej.

2. Dominacja formalnych celów kształcenia widoczna w programach nauczania z lat 1920-1922, zwlaszcza dla siedmioletniej szkoły powszechnej, była związana z wpływem idei „nowego wychowania", które znalazły nie tylko swoje odbicie w formułowanych w nich celach, ale także w metodach i formach nauczania.

3. Idee „nowego wychowania”, głównie nauki całościowej, doprowadziły do upraktycznienia celów nauczania języka polskiego i przyrody, szczególnie na poziomie nauki elementarnej, a psychologizm „nowego wychowania", wydając się współczesnym tak bardzo postępowym, spowodował zmniejszenie się krytycyzmu wobec tego kierunku. Zgodnie z jego założeniami dziecko pojmowano jako indywidualna istotę $\mathrm{i}$ umiejscawiano właściwie w pustce społecznej. Ten subiektywizm pedagogiczny, oparty na indywidualizmie psychologicznym wpłyną na formułowanie

${ }^{32}$ H. Balińska, Idee przewodnie w programach nauczania poczalkowego w latach 1918-1975 [w:] Idee przewodnie w programach szkoty..., s. $62-63$. 
ogólnych celów nauczania, powodując ich nieokreślonośc i trudności interpretacyjne. Wskutek tego dobór treści nauczania miał charakter tradycyjny, gdyż psychologiczne pojmowanie celów, prowadzące do formalizmu dydaktycznego nie decydowało o jakości tego doboru, lecz jedynie o ilościowym ograniczeniu materiału nauczania.

4. Idea psychologizmu, która stała się dominująca teorią w interpretacji zadań, celów i treści wykształcenia ogólnego na wszystkich poziomach kształcenia, obniżyła jego wartość. Akcentując rozwój umysłowy, jak gdyby w izolacji od treści, zaburzyła prawidłowe relacje pomiędzy celami określającymi treści poznania a potrzebami wszechstronnego rozwoju człowieka. Wartość wykształcenia została uzależniona od subiektywnych właściwości ucznia i metod pracy, a nie od celów. Przesadny indywidualizm, formalizm dydaktyczny, nieokreśloność celów kształcenia nie dawały pełnego rozumienia życia społecznego i otaczajacego dziecko świata.

Nic więc dziwnego, że społeczeństwo polskie niezadowolone z takiego modelu szkoły, zarówno powszechnej, jak i średniej, poddawało go wszechstronnej krytyce. Niezadowolenie spoleczeństwa „motywowało" Ministerstwo do poprawiania programów, w tym również formułowanych w ich obrębie celów kształcenia oraz rozpoczęcia i prowadzenie prac nad przygotowaniem nowej reformy szkolnej.

Aneks nr 1

Zestawienie celów nauczania języka polskiego i przyrody zawartych w programie nauczania dla siedmioletniej szkoły powszechnej w latach 1920 - 1922

\begin{tabular}{|c|c|}
\hline $\begin{array}{l}\text { Cele nauczania języka polskiego w programie } \\
\text { nauczania dla 7-letniej szkoły powszechnej } \\
(1920-1922)\end{array}$ & $\begin{array}{l}\text { Cele kształcenia przyrody w programie naucza- } \\
\text { nia dla 7-letniej szkoły powszechnej } \\
(1920-1922)\end{array}$ \\
\hline $\begin{array}{l}\text { 1. Rozumienie mowy, która w obcowaniu co- } \\
\text { dziennym posługuje się ogół narodu polskie- } \\
\text { go; } \\
\text { 2. Rozumienie języka książkowego: a) prozy } \\
\text { autorów popularnych, tj. języka tych ksiazżek, } \\
\text { z pomoca których uczeń po skończeniu szkoły } \\
\text { uzupełniać będzie swe wykształcenie; b) języ- } \\
\text { ka poetyckiego (pięknego) popularnych auto- } \\
\text { rów; } \\
\text { 3. Praktyczne opanowanie języka: a) swobodne } \\
\text { i poprawne wyrażanie się w piśmie w zakresie } \\
\text { życia codziennego; } \\
\text { 4. Wzbudzenie zamiłowania i wyrobienie uzdol- } \\
\text { nienia do czytania jako środka kształcącego } \\
\text { umysł i serce; } \\
\text { 5. Wzbudzenie świadomej miłości języka ojczy- } \\
\text { stego. }\end{array}$ & $\begin{array}{l}\text { 1. Zaznajomienie } \mathrm{z} \text { najważniejszymi zjawiskami } \\
\text { i prawami przyrody żywej i martwej oraz ich } \\
\text { zastosowaniami praktycznymi; } \\
\text { 2. Zaprawienie do bystrej i ścisłej obserwacji } \\
\text { i wyrobienie zdolności logicznego myślenia; } \\
\text { 3. Wyrobienie inicjatywy i samodzielności } \\
\text { w pracy, zręczności i praktyczności. }\end{array}$ \\
\hline
\end{tabular}

Źródło: Program nauki w szkołach powszechnych siedmioklasowych. Język polski, Warszawa 1920 oraz Program nauki w szkołach powszechnych siedmioklasowych. Przyroda, Warszawa 1921. 


\section{WYDZIAL HUMANISTYCZNY}

Cele nauczania języka polskiego w programie nauczania dla gimnazjum państwowego

1. Ze względu na materiał nauczania:

A. W zakresie poznawania i opanowywania języka: nauczyć poprawnie i biegle mówić i pisać; doprowadzić do zrozumienia podstawowych właściwości współczesnego jezzka polskiego $\mathrm{z}$ uwzględnieniem jego rozwoju w ciagu wieków ubiegłych;

B. W zakresie lektury: nauczyć czytać utwory prozaiczne i poetyczne z należytym zrozumieniem i odczuwaniem ich treści i formy, nauczyć analizowania, wyjaśniania i samodzielnego przyswajania sobie tekstów, wzbudzić zamiłowanie do lektury; doprowadzić do gruntownego przyswojenia sobie wybranych arcydzieł literatury polskiej i powszechnej; wprowadzić za ich pośrednictwem w dziedzinę kultury narodowej (z uwzględnieniem różnych jej faz i kierunków) oraz ogólnoludzkiej;

2. Ze względu na cele formalne nauczania szczególnem zadaniem nauczyciela języka polskiego jest:

A. Wdrożyć do możliwie pełnego i konkretnego ujmowania zjawisk życia, a przede wszystkim świata wewnętrznego człowieka;

B. Zaprawić do jasnego, rzeczowego i możliwie samodzielnego myślenia, kształcić wyobraźnię i smak estetyczny, uszlachetniać i rozwijać uczucia;

C. Wychowywać czlowieka i obywatela przez wpajanie świadomej miłości języka ojczystego i kultury narodowej, a na jej gruncie szczepienie i pielęgnowanie ogólnoludzkich ideałów religijnych, naukowych, estetycznych.
Cele nauczania przyrodoznawstwa w programie nauczania dla gimnazjum państwowego

1. Z punktu widzenia rzeczowego: przyswojenie elementarnego pojęcia o istocie żywej (życie organizmu w związku z jego budowa wewnętrzną i zależności od środowiska);

2. Z punktu widzenia wychowawczego: wyrabianie w uczniach stosunku badawczego względem konkretnych zjawisk natury w ogóle (kształcenia umiejętności spostrzegania i eksperymentowania); w szczególności zaś wyzyskanie wartości wychowawczych, związanych ze swoistością samego przedmiotu, mianowicie: a) kształcenie w trafnem ujmowaniu całości przez ćwiczenie umysłu, na wypadkach konkretnych, w rozważaniu wzajemnego stosunku funkcjonalnego i konstrukcyjnego składników do całości; b) kształcenie w ogarnianiu całości skomplikowanego i długotrwalego procesu (jakim jest istota żywa), w rozkładaniu go na kolejne momenty $i$ wiązaniu tych momentów ze soba; c) kształcenie zdolnoścj dostrzegania zwiazku pomiędzy konstrukcja, funkcja i warunkami, zatem ćwiczenie zdolności interpretacji, oraz zdolności konstrukcyjnych;

3. Wreszcie, w związku z odpowiednimi częściami kursu, zwłaszcza nauki o ciele ludzkim, udzielenie uczniom podstawowych wiadomości z higieny. 


\section{WYDZIAŁ MATEMATYCZNO-PRZYRODNICZY}

\begin{tabular}{|c|c|}
\hline $\begin{array}{l}\text { Cele nauczania języka polskiego w programie } \\
\text { nauczania dla gimnazjum państwowego }\end{array}$ & $\begin{array}{l}\text { Cele nauczania przyrodoznawstwa w programie } \\
\text { nauczania dla gimnazjum państwowego }\end{array}$ \\
\hline $\begin{array}{l}\text { Cele nauczania takie same jak dla wydziału } \\
\text { humanistycznego }\end{array}$ & $\begin{array}{l}\text { 1. Z punktu widzenia rzeczowego: przyswojenie } \\
\text { przez uczniów zgodnych z nauka pojęć o is- } \\
\text { tocie żywej na miejsce błędnych pojęć gmin- } \\
\text { nych, zatem: przyswojenie pojęcia o życiu } \\
\text { ustroju w zwiazku z jego budową i w zależno- } \\
\text { ści od środowiska; wstępne przygotowanie do } \\
\text { pojęcia pokrewieństwa i ewolucji; } \\
\text { 2. Z punktu widzenia wychowawczego: (cele } \\
\text { takie same jak na wydziale humanistycznym), } \\
\text { a ponadto: } \\
\text { - kształcenie umiejętności porównywania } \\
\text { i ujmowania analogii, wykrywania osobliwo- } \\
\text { ści, uogólniania, samodzielnego klasyfikowa- } \\
\text { nia, tworzenia realnych pojęć i definicji; } \\
\text { - przyzwyczajanie do ostrożności w rozszerza- } \\
\text { niu pojęć, zdobytych na pewnej liczbie wypa- } \\
\text { dków konkretnych, na inne wypadki, przez } \\
\text { wykazywanie wyjatków i w ogóle granicy } \\
\text { stosowania tych pojęć; } \\
\text { 3. Wreszcie, w zwiazku z odpowiednimi częś- } \\
\text { ciami kursu, zwłaszcza nauki o ciele ludzkim, } \\
\text { udzielenie uczniom podstawowych wiadomo- } \\
\text { ści z higieny. }\end{array}$ \\
\hline
\end{tabular}

Źródło: Program gimnazjum państwowego, wydział humanistyczny, Warszawa 1922 oraz Program gimnazjum państwowego, wydziat matematyczno-przyrodniczy, Warszawa 1922.

Agnieszka Watega

Toruń

\section{Wanda Szuman (1890 - 1994) - zarys życia i działalności pedagogicznej}

\section{Uwagi wstępne}

Wanda Szuman była pedagogiem, psychologiem oraz opiekunem ludzi kalekich. Pracowała także niezwykle aktywnie $w$ różnorakich organizacjach spolecznych i pedagogicznych. Córka znanego lekarza Leona Szumana, siostra wybitnego psychologa i wykładowcy Uniwersytetu Jagiellońskiego Stefana Szumana, całym swoim działaniem społeczno-pedagogicznym dopisała kolejną wspaniałą kartę do dziejów rodziny. Podsumowanie tego niezwykle aktywnego życia zamknęła w jednym prostym 